\title{
A SNAPSHOT OF THE USE OF READING METHODS IN PRIMARY SCHOOLS IN THREE PROVINCES OF SOUTH AFRICA
}

\author{
Anna Hugo \\ University of South Africa
}

\begin{abstract}
The teaching of reading is not as easy as it may seem. It requires specific knowledge and the use of reading methods by teachers. Learners' reading needs and learning styles also have to be considered. According to the Progress in International Reading Literacy (PIRLS) results for 2016, the reading abilities of South African learners are far below the international standard as set out by PIRLS.

There is a lack of research about the strategies and methods that primary school teachers use to teach reading. In this article, the feedback regarding reading methods - gathered from 36 primary school teachers in three provinces - is discussed. The data revealed that most of the Grade 1 to 7 teachers who participated in the research knew and used some of the six reading methods under discussion. However, the results did not indicate how well the teachers applied these methods and how versatile they were in using the different reading methods. The data revealed that Foundation phase teachers used some of the methods statistically significantly more often than the comparison group of Intermediate phase teachers in a nonexperimental static-group observational design study.
\end{abstract}

According to Spaull (McBride 2019:1), a well-known researcher in South Africa, one of the three main reasons why Foundation phase readers are struggling with reading is that their teachers do not know how to teach reading systematically. Teachers do not know how to change and adapt the methods that they use to teach reading and not enough research has been done to address the problems with the teaching of reading in the classroom specifically. Often the reading problems experienced in the Foundation phase are carried over to the Intermediate phase.

Keywords: primary schools, reading methods, teachers' ability to change reading methods, teachers' use of reading methods

\section{INTRODUCTION}

Reading forms the foundation of all areas of learning at school as well as the post-school level; therefore, it is important that all learners attain proficiency in reading. If a learner cannot read with understanding, how can he or she make progress at school? As far back as 2004, UNESCO already stated: 'Since reading forms the basis for all other areas of learning, it is necessary to ensure that children in the primary grades attain proficiency in reading' (UNESCO 2004:3). 
It is not an easy task to teach a skill such as reading which is crucial for learners to progress academically at school and to make a success of their lives. It requires teachers to understand how to teach reading to learners with different abilities and needs. The teaching of reading which is done during the early years at school lays the foundation for literacy learning. Thus, when teachers teach reading, they have to train learners at all levels 'to prepare ideas, critically analyse arguments, synthesize information from multiple sources and use reading to build their knowledge' (National Research Council 2010:75).

In a study about the influence of the choice of three methods to teach reading, Ofuani and Gbenedio (2016:21) found that the method used to teach reading plays a major role in the achievement of learners as regards reading and reading comprehension. They opine that if the right method is used, it can boost learners' performance in reading. Ariandika and Kartikawati (2018:284) aptly state that the teaching of reading is not as easy as most people think and that it is actually the job of an expert.

South Africa has been part of the Progress in International Reading Literacy (PIRLS) programmes for numerous years. The 2016 report revealed that out of 50 countries in which 12000 schools participated, South Africa obtained the lowest overall score of 321 points which was 261 points below that of Russia, the highest achieving country (Mullis, Martin, Foy \& Hooper 2017:3). The 2016 PIRLS report also showed that $78 \%$ of the Grade 4 learners in South Africa could not read and comprehend a text (Ollis 2017:1). At 406, the average score of the Grade 5 learners in South Africa was almost 100 points below the PIRLS centre point of 500 (Mullis et al., 2017:21). This fact is especially concerning considering that during the Foundation phase, learners learn to read in comparison to the Intermediate phase and onwards when learners have to read to learn.

According to Rule and Land (2017:2308), much quantitative research exists about the problems with reading in South Africa's primary schools. There is, however, a lack of research about the strategies and methods that primary school teachers use to teach reading. Le Cordeur (2010:56) opines that Foundation phase teachers tend to use the traditional approach to teach reading which consists of the teaching and decoding of sounds. The use of other reading methods and research about it is neglected.

The purpose of this article is to provide a snapshot of the reading methods that teachers in primary schools in three provinces of South Africa apply in their classrooms. More advanced reading methods and strategies such as skimming and scanning as well as speed reading will not be discussed in this article. The focus will be on initial reading - which has to be taught in the Foundation phase - and the methods that teachers use. Although certain methods are predominantly used in the Foundation phase, they also have to be used by teachers in Grades 4 to 6 and onwards when learners in their classes have to be provided with additional or remedial reading support because of poor reading skills emanating from the Foundation phase.

\section{CURRICULUM AND ASSESSMENT POLICY AND THE TEACHING OF READING}

The teaching of reading is clearly set out in the Curriculum and Assessment Policy (CAPS) documents of the Department of Basic Education for grades R-3 and 4-6. In both documents, the importance of acquiring reading and viewing skills for success at school is emphasised. The CAPS document for the Foundation phase describes two reading methods namely 
phonics and word recognition (sight words) - also known as the look-and-say method (National Department of Basic Education 2011(a):15-16).

The CAPS document for grades 4-6 encourages teachers to build on the foundation for reading established in grades $\mathrm{R}-3$. Teachers are advised to use methods such as reading with and to the class, guided group reading and pair reading. The CAPS document for grades 4-6 emphasises the importance of comprehension in reading - how important it is to be able to read to learn (National Department of Basic Education 2011(b):11). However, this document does not explain what teachers can do if their learners still cannot read. The result is that most of the time learners with reading problems in Grades 4 to 6 are not supported.

\section{READING METHODS}

\section{Phonics or the Phonic Method}

The phonic method (phonics) is widely used in South Africa to teach reading. One reason could be that apart from English, the other languages spoken in South Africa have a greater sound-symbol correspondence and therefore young learners can match letters to their specific sounds more easily (Teacher Education in sub-Saharan Africa TESSA). When it comes to English, the situation changes: English has 44 phonemes (sounds) that are represented by the 26 letters of the alphabet.

The phonic method for teaching reading is regarded as a bottom-up process because it starts with single letters, which are the smallest units in a language. Learners have to learn individual letters and the features of those letters as well as the sounds that the letters represent. The relationship between letters and sounds in a word or text is thus essential. In this method, phonemic awareness (the ability to separate the sounds of a language) is important as well as the ability to process words quickly (author). It is an excellent method for introducing young learners to the written form of the various sounds found in the language that is used as the language of learning and teaching in their classrooms.

Knowledge of the written form of sounds makes it possible for learners to decode most words. The phonic method relies on auditory perceptual skills initially and then on visual ability to remember and recognise letters and letter groups. According to Carrell (1988 in Le Cordeur 2010), the bottom-up reading method is a systemic model departing from the written word. First, letters must recognised, then the sounds are decoded to form words and thereafter the words have to be recognised.

When only phonics is used, learners tend to sound out many words and the meaning of the text often gets lost. Byrski (2009) warns that concentrating on decoding skills when teaching reading can be disastrous. Quite often it is the standard method during reading lessons in primary schools. It is also said that if a person knows the sound system of a language, he or she can 'read' any language without understanding what is read, or can be doing what is known as 'barking at print' (Oxley, 2014). It is thus advised that planned phonics instruction should be integrated with other reading methods to create a more balanced approach to the teaching of reading (Riddle, 2015). 


\section{The Look-and-Say Method}

The look-and-say method, also known as the whole-word or whole-language method which becomes the whole-sentence method to teach reading, is regarded as a psycholinguistic view of reading. Reading is considered to be a top-down process since it goes from the whole (words) to the parts (which are letters). When this method is used, learners first learn to read words, then sentences and finally, a story. They also learn the shape of the words; the words are initially accompanied by pictures.

This method links words and their respective meanings right from the start and it relies very much on a learner's visual memory (Joubert, 2013:110-112). The look-and-say method is also useful when sentences are being read. Regarding the reading of sentences, GarcíaMadruga, Elosúa, Gil, Gómez-Veiga, Vila, Orjales, Contreras, Rodríguez, Melero and Duque (2013:155) stress the importance of the automatic recognition of a large vocabulary, especially in the upper grades, because it supports text comprehension.

According to Alderson (2000 in Le Cordeur 2010), the top-down reading method is holistic and consists of systems. The various systems cannot be separated. Readers have to guess the meaning of the text based on the minimal information in the text while using existing activated knowledge to the maximum at the same time. It is especially nonvisual information that helps to explain the text.

English being a language with phonological complexity, poses problems with some words and sounds. Tshuma and Le Cordeur (2017:713-714) discuss another problem with English and everyday words whose meaning change when used in school mathematics. Examples of these words are: above, altogether, angle, as great as, average, base, below, between, big, bottom, change, circular, collection, common, complete, coordinates, degree, difference, different, differentiation, divide, down, element, even, expand, face, figure, form, grid, high, improper, integration, leaves, left, little, low, make, match, mean, model, moment, natural, odd, one, operation, overall, parallel, path, place, point, power, product, proper, property, radical, rational, real, record, reflection, relation, remainder, right, root, row, same, sign, significance, similar, small, square, table, tangent, times, top, union, unit, up, value, volume and vulgar.

If only the look-and-say method is used to teach reading, learners may experience difficulties pronouncing unknown words. The reason is that the meaning of the words is important and taught firstly but the words are not broken down into sounds. If a child does not recognise a word, he or she can become lost in the reading process. The look-and-say method is, however, very useful for improving fluent reading and for words of which the spelling does not match the sounds.

\section{The Combined or Eclectic Reading Method}

This method combines the phonic method and the look-and-say method. It is often used in classrooms and can be regarded as a successful method for teaching reading. In an article Strauss (2019) refers to the 'reading wars': 'that seemingly never-ending battle about how to best teach reading to students - systematic phonics or whole language'. This war has been ongoing for many years. People involved in language philosophy do, however, conclude that the whole-language method cannot be used on its own. A basis of phonics instruction is always needed to assist readers in decoding words and reading independently (Strauss 2019). 


\section{THRASS}

THRASS stands for Teaching Handwriting, Reading and Spelling Skills and is a phonics programme that utilises pictures to show the various sounds represented by letters. It moves away from the traditional notion that one letter makes one sound. It shows for instance, that the letter 'a' makes a different sound in words like ant, banana, zebra, swan, ball and baby. Each of these words is accompanied by a beautiful picture (www.thrassafrica.co.za).

Although THRASS is a phonics programme relying on auditory skills initially, it also uses words that the learners can read with the help of pictures and so their visual abilities are drawn in as well. 'Using the THRASS methodology, children's reading, spelling, auditory, visual, sequential and spatial perceptual skills are all improved.' (www.thrassafrica.co.za).

Where available to teach reading in English, the THRASS programme can be very useful as both the sounds and the whole words are presented to learners. During a discussion with the managing team of THRASS in Johannesburg, it was mentioned that the THRASS programme is at the moment only available in English but it is being developed to be used for Afrikaans and isiZulu speaking learners as well. The programme requires attendance of a two-day THRASS training session before it may be used by teachers or sold to schools. This requirement could hamper country-wide distribution and use of the programme.

\section{The Bilingual Method}

The bilingual method encompasses the use of two languages to teach reading. This could be helpful in a country such as South Africa where many learners are taught to read English as their second language. The majority of learners, especially in the Intermediate phase and onwards, are also taught in English as a second language. Concerning the Intermediate phase, Tshuma and le Cordeur (2017) opine that learners' cognitive abilities to think are developed naturally in their home languages. When they are taught in a second language such as English, learners' language skills in the language of learning and teaching could thus be developed by using the mother tongue. Keywords and teaching materials should be made available in the learners' home language also so that the learning material is in both languages.

Reading problems may continue in the Intermediate phase where the majority of learners in South Africa are expected to learn through the medium of English as their second language. Genesee (2019:3) aptly states that it is obvious from worldwide research that when learners are able to use knowledge and abilities from their home languages to master reading, these reading skills can be transferred to learning English as a second language. Intermediate phase teachers could accordingly use the bilingual method to help learners who are experiencing reading problems.

\section{The Language Experience Method}

The language experience method for teaching reading employs learners' own knowledge and use of words - their own oral language. Because learners' personal use of language and the type of words that they use are incorporated into the language experience method, the text they eventually have to read is usually at their level and easier and more interesting to read. In a toolkit for teaching, the Australian Department of Education (2019) states in this regard: 'As the language experience texts are relevant to the students, the opportunity to read them 
aloud creates a positive experience and reinforces the reciprocity between reading and writing. Texts that the students have produced based on their experiences, using familiar language make good early reading material which can be read chorally'. The language experience method is very useful for remedial reading for individual learners.

\section{The Use of the Internet to Access Stories to Be Read in the Class}

Technology is becoming part and parcel of life and it is hoped that teachers will be able to use technology to support them in teaching reading. It could become an asset if teachers (especially in the remote and under-equipped schools in South Africa) use the internet to get new stories to read to their learners and to be read by the learners. Even though the use of the internet to access stories is not a reading method, this question was added to the questionnaire to determine to what extent the internet is used to support the teaching of reading in some primary schools.

Roig-Vila and Mengual-Andrés (2014:438) state that technology can support and strengthen reading and the teaching of reading. Technology also offers special input when teaching reading such as speed, reliability, fewer costs to access reading materials and easy access to information. The many possibilities that reading has, as well as its social and individual importance, become more powerful with the use of technology (Calderón-Rehecho, 2012:11). Picton (2019) reports that teachers in primary schools remarked that the use of technology had a positive impact on their learners' motivation and enjoyment of reading. Technology was also seen by most teachers to have a positive influence on learners who are reluctant to read.

\section{METHODOLOGY}

\section{The Research Design and Measuring Instrument}

The quantitative approach followed in this study consisted of a closed-ended questionnaire to collect data on the methods used to teach learners to read in primary schools. Only a section of the questionnaire is relevant to this paper; that section includes questions that probe how frequently teachers in primary schools use the six reading methods outlined in the literature study of this paper.

These questions prompted participants to select the frequency-of-use option level most appropriate to the use of these six methods for learning to read. An additional question on the use of the internet to search for stories to read in the classroom was also answered on the same frequency-of-use scale. The Likert scale was used in the questionnaires. The Likert frequency-of-use (LaMarca 2011) rating options of the scale ranged from ' 1 ' indicating frequency of use as never, '2' indicating infrequently, '3' indicating use as sometimes, '4' indicating use as frequently or very often and '5' indicating frequency of use as always.

Originally, a group of primary school teachers were approached randomly to complete the questionnaire electronically but this yielded no response from the teachers. The same occurred when hard copies of the questionnaire were sent to the teachers.

The researcher subsequently decided to use four reliable field workers to distribute and collect the questionnaires to primary school teachers in the vicinity where they lived. Forty questionnaires were distributed and 38 were completed and returned. This convenience- 
sampled group therefore had a response rate of 95\%. In this article, the response data of 36 questionnaires will be used because two of the questionnaires were completed by Grade R teachers and Grade $\mathrm{R}$ teachers do not normally teach reading.

Permission for the research was obtained from the Ethics Committee in the College of Education to which the researcher is attached. The questionnaire was completed by teachers in three of the provinces in South Africa. The schools are not located in big cities but are also not in deep rural areas, they are situated in big towns or townships. No data was collected from private schools. The reason for this decision was to control the environmental and background variability between private schools and governmental schools. It is hoped that the data will yield insight into the classrooms of ordinary governmental schools in which the majority of learners in South Africa are taught. In most of the classes there were 40 to 50 learners, one class had 54 learners and a few classes had 25 to 36 learners. Most of the teachers who participated had the difficult task of teaching large groups of learners.

Of interest to this study was the status of the use of learning-to-read methods in the Foundation phase compared to the use of learning-to-read methods used in the Intermediate phase classrooms. Once the data had been collected and entered onto an Excel spreadsheet, the necessary analyses were conducted using the statistical software package SAS (Statistical Analysis System) version 9.1 and Excel version 2003. The results of these analyses are presented in the next section.

\section{Motivation for the Nonexperimental Static Group Research Design of This Study}

The choice of an appropriate research design for this study was influenced by the research objectives of the study as well as the research background. These aspects are briefly outlined in the following two paragraphs to indicate how a nonexperimental static group design (Engel and Schutt, 2014: 130-133) was deemed an appropriate research design for this research.

The objective of the study was to obtain reliable estimates of Foundation phase teachers' use of the six reading methods (phonic, look-and-say, eclectic, language experience, bilingual, THRASS) and the use of the internet. The current status of Foundation phase teachers' use of reading methods was thus at stake. The question arises whether such estimates of the use of reading methods might not carry more weight if interpreted against a sensible comparison group. A comparison group will enable researchers to evaluate whether Foundation phase teachers use a specific reading method more intensively or less intensively measured against the comparison group.

Research argues that Intermediate phase teachers constitute a sensible comparison group since learning-to-read in the Foundation phase turns to reading-to-learn in the Intermediate phase. The frequency-of-use of reading methods is therefore assumed to decrease from the Foundation to the Intermediate phase classroom. This could serve as an indicator of how the status of Foundation phase teachers' use of reading methods compare to that of Intermediate phase teachers. The former is expected to be higher than the latter. The nonexperimental static-group design mentioned previously provides for the inclusion of a comparison group in its model.

With regard to the research setting of the current study, it was practical to sample teachers by way of convenience sampling and not randomised sampling as explained in the sampling subsection of the methodology section. Furthermore, the data collected in this study consisted 
of teachers' use of specific reading methods. This implies that reading methods, which constitute the 'treatment' in the research model, had already commenced by the time the study was undertaken.

The nonexperimental static-group research design which is deemed suitable for the current study accommodates two nonrandomised groups (the Foundation and Intermediate phase teachers in the current study) in the model. One group serves as a comparison group. Identification of a sensible comparison group (the Intermediate phase teachers in the current study) is integral to this model. Engel and Schutt (2014: 136) furthermore state that this design is often used when a 'treatment' or programme has already commenced when research is undertaken, as happened in this study.

\section{Analysis Strategy and Statistical Software}

Once the data had been collected and entered into an Excel spreadsheet, the necessary analyses were conducted using the statistical software package SAS (Statistical Analysis System), version 9.1, and Excel, version 2003. The data entered consisted of the frequency-ofuse rating scores (1-5) as each respondent awarded a value to each of the reading methods (Phonics, Look-and-say, Eclectic, Language experience, Bilingual, THRASS, Internet use) listed in the questionnaire.

Since the objective of the study was to determine the status quo of the frequency-of-use of the various reading methods (and internet-use) of Foundation phase teachers and to compare these determined estimates of use against the frequency-of-use of Intermediate phase teachers, statistical analyses deemed appropriate included:

(i) Frequency tables to indicate frequency-of-use for each of the six methods and the internet, reported in tables for all respondents, and separately for Foundation and Intermediate phase teachers.

(ii) Stacked bar graphs to visually illustrate and compare Foundation- and Intermediate phase-frequency proportions over the various levels of the frequency-of-use rating scale for each reading method.

(iii) Two-sample Wilcoxon rank-sum tests for each reading method performed on the Foundation and Intermediate phase frequencies reported for each frequency-of-use rating level.

This was done to compare and evaluate how Foundation phase teachers measure up to the Intermediate phase teachers regarding a specific reading method. For example, do they use the specific method more or less frequently than the comparison group or are the frequencyof-use response patterns not significantly different from one another? Descriptive statistics on the mean frequency rating of each group were also calculated. The results of these analyses are presented in the next section.

\section{DATA ANALYSIS}

\section{Frequency-of-Use Response Patterns for the Six Reading Methods}

The six reading methods discussed earlier are phonics or the phonic method, the look-and-say method, the combined or eclectic method, THRASS, the bilingual method, and the language experience method. The frequency table included in the stacked bar graph in Figure 1 below 
reports participants' response patterns over frequency-of-use rating levels (always, very often, sometimes, infrequently, never) per reading method (phonic, look-and-say, eclectic, language experience, bilingual, THRASS) and use of the internet to access stories to be used in the classroom. The stacked bar graph visualises these response patterns.

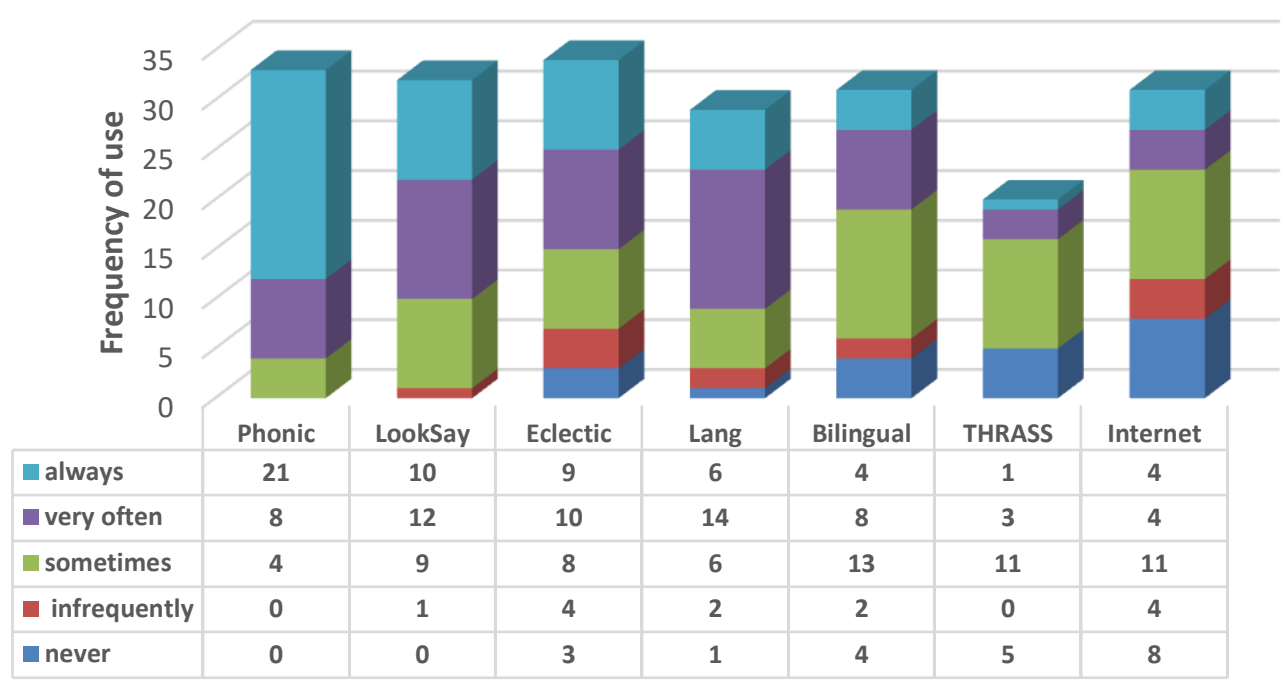

\section{Figure 1 Stacked bar graph of frequency-of-use responses}

Questionnaires were also completed by teacher participants who taught Grade 7 classes. For the purpose of this study, their responses were added to the Intermediate phase group of respondents.

In the stacked bar graph, the proportion of always and very often rating level frequencies was compared across the different methods for all respondents; the graph suggests that in general, the method most often used (the light blue and purple sections) is the phonic method, followed by the look-and-say and language experience methods. Proportionately, the bilingual method and THRASS are used less often.

It can be deduced that most of the teachers are acquainted with the phonic method and the look-and-say method. The eclectic method that combines the advantages of the phonic method and look-and-say method is used less often. Considering the always and very often rating options, the eclectic method reported a tally of 19 (of a total of 35) responses over these two frequency-of-use levels, compared to frequencies of 29 and 22 (of a total of 3) respectively for the mentioned rating levels of the phonic and look-and-say methods.

\section{Foundation Phase and Intermediate Phase Response Patterns for Six Reading Methods}

Up to this point, the frequency distributions of reading methods over frequency-of-use responses provided a general overview of the use of reading methods by all teacherparticipants. However, it may be asked, how Foundation phase and Intermediate phase 
teachers measure up with respect to the use of reading methods. This matter is dealt with by introducing a Foundation phase and Intermediate phase distinction in the response dataset.

Therefore, the frequency table included beneath the bar graphs in Figure 2 below reports participants' response patterns over frequency-of-use rating levels (always, very often, sometimes, infrequently, never), per participant group (Foundation phase and Intermediate phase) reading method (phonic, look-and-say, eclectic, language experience, bilingual and THRASS) and the question of the use of the internet.

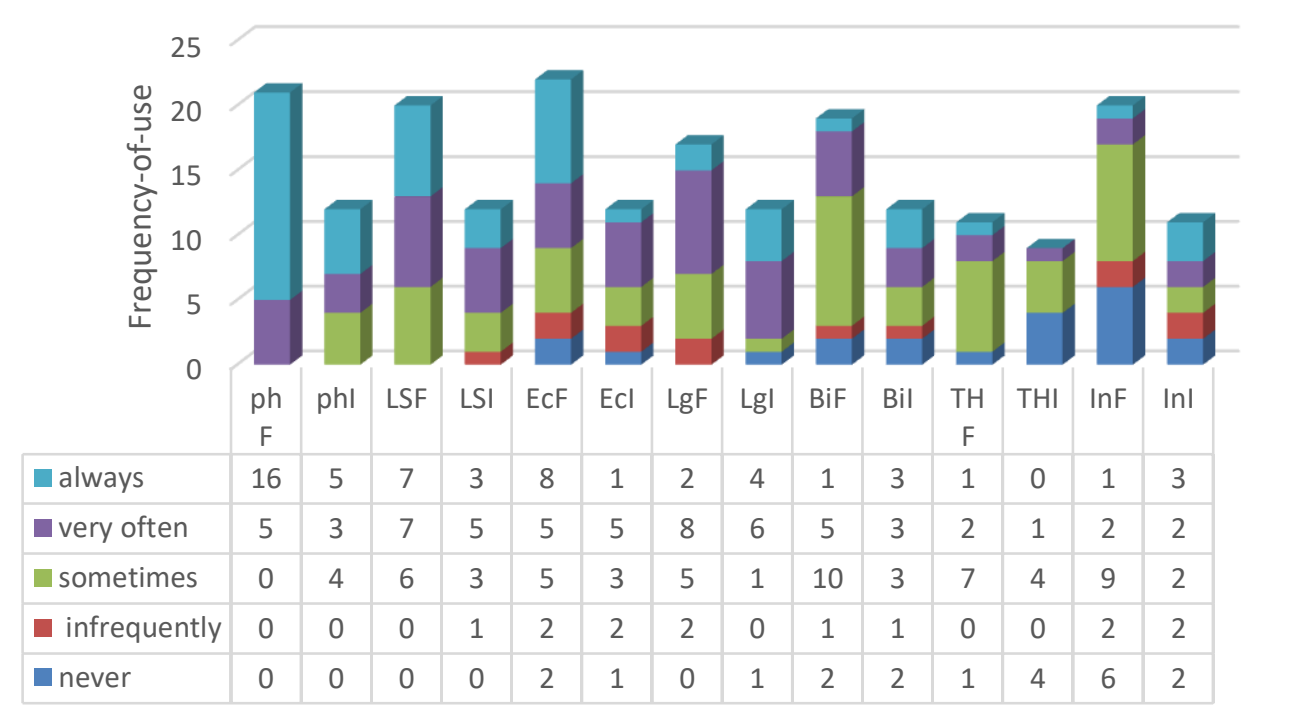

Figure 2 Stacked bar graph of the frequency-of-use response patterns of Foundation phase and Intermediate phase teachers to the six reading methods and internet-use

Legend:

\begin{tabular}{|c|c|}
\hline Foundation phase & Intermediate phase ......... \\
\hline PhF - Phonic method & PhI - Phonic method \\
\hline LSF - Look-and-say & LSI - Look-and-say \\
\hline EcF - Eclectic method & EcI - Eclectic method \\
\hline LgF - Language experience & LgI - Language experience \\
\hline BiF - Bilingual method & BiI - Bilingual method \\
\hline THF -THRASS & THI -THRASS \\
\hline InF - Internet use & InI -Internet use \\
\hline
\end{tabular}

Examination of the proportion of frequencies recorded for the always and very often rating levels (light blue and purple sections of the bar) of Foundation phase participants compared to Intermediate phase participants suggests different usage patterns for some reading methods. For example, the mentioned proportion for the Foundation phase teachers' use of the phonic method appears to be substantially greater (frequency of 21 of 21 total responses i.e., $100 \%$ ) than that of the Intermediate phase respondents (frequency of 8 of 12 total responses i.e., 66.67\%). This suggests a difference in the use of the phonic method. 
It should be kept in mind that Grade 4 to 6 learners are supposed to have already acquired reading skills and that teachers only use this method to support learners who experience reading problems in the Intermediate phase. This result shows that the choice of Intermediate phase teachers as comparison group was sensible because the deduction can now be made that in the learning-to-read phase (Foundation phase), the teachers seem to use the phonics method extensively compared to the Intermediate phase (the comparison group) where learners have to read to learn. This would explain seemingly different frequency-of-use response patterns for phonics.

The bar graphs and frequency table also suggest possible differences in the always and very often frequency response patterns of the Foundation phase compared to the Intermediate phase for the language experience and bilingual methods with always and very often responses of 10 (of 17 or $50.82 \%$ ) and 10 (of 12 or $83.33 \%$ ) respectively for the Foundation and Intermediate phase groups for the language experience method and 6 (of 19 or $31.58 \%$ ) and 6 (of 12 or $50.0 \%$ ) respectively for the Foundation and Intermediate phase groups for the use of the bilingual method. In this instance, the results of the comparison group (Intermediate phase teachers) now suggest not extensive use of these methods in the Foundation phase compared to the Intermediate phase comparison group.

The question arises whether more specific deductions regarding these suggested differences in the response patterns of Foundation and Intermediate phase teachers' use of reading methods can be made. In other words, can statistical significance be attached to the findings discussed in this section? The next section reports the results of six two-sample Wilcoxon rank-sum tests. These tests determine whether the suggested Foundation and Intermediate phase frequency-of-use response pattern differences for the six reading methods are statistically significant.

The Wilcoxon rank-sum test (also referred to as the Wilcoxon two-sample t-test) is a nonparametric alternative to the two-sample t-test in instances where the requirement of normally distributes data becomes questionable. The Wilcoxon rank-sum test is distributionfree and is solely based on the order (magnitude) of the observations (frequencies) from the two samples: For each reading method, ranks are awarded to the frequencies reported for each of the always, very often, sometimes, infrequently, never levels over the Foundation and Intermediate phase group responses; a Wilcoxon rank-sum test is then performed on these joint ranks (Greenberg 2009: 130-133) to determine whether the distribution of frequencies over the frequency-of-use level for Foundation and Intermediate phase groups are similar or differ statistically significantly.

\section{The Wilcoxon Rank-Sum Test Results}

The results of the Wilcoxon tests for each reading method (and internet use by teachers) are reported in the highlighted third row of each reading method subtable of Table 1 . The first two rows of each subtable also report the mean frequency-of-use rating for Foundation phase (row 1) and Intermediate phase (row 2) teacher participants as well as the standard deviation from the mean and the minimum and maximum recorded level of frequency-of-use rating response to any reading method. If statistical significance is indicated for a specific reading method, it can be assumed that the two-mean frequency-of-use ratings for the Foundation and Intermediate phase teachers differ for the particular reading method or use of the internet variable. 
Table 1: Means and summary statistics of the frequency-of-use rating responses for the six reading methods for Foundation and Intermediate phase teacher participants

\begin{tabular}{|c|c|c|c|c|c|c|}
\hline $\begin{array}{l}\text { Results of } t \\
\text { lines }\end{array}$ & Wilcoxon rank- & & e lis & for ea & nothod & the colo \\
\hline Item & Grade Category & $\begin{array}{l}\mathbf{N} \\
\text { Obs }\end{array}$ & Mean & Std Dev & Minimum & Maximum \\
\hline Phonics or & Foundation phase & 24 & 4.76 & 0.44 & 4.00 & 5.00 \\
\hline phonic & Intermediate phase & 12 & 4.08 & 0.90 & 3.00 & 5.00 \\
\hline method & Wilcoxon two-samp & t-test, & $=-2.33$ & $; P(Z<-2$ & $33)=0.01$ & \\
\hline & Foundation phase & 24 & 4.05 & 0.83 & 3.00 & 5.00 \\
\hline LOOK d & Intermediate phase & 12 & 3.83 & 0.94 & 2.00 & 5.00 \\
\hline & Wilcoxon two-samp & t-test. & $Z=-0.56$ & $\mathrm{P}(\mathrm{Z}<-0$ & 56) $=0.28$ & \\
\hline & Foundation phase & 24 & 3.68 & 1.32 & 1.00 & 5.00 \\
\hline Eclectic & Intermediate phase & 12 & 3.25 & 1.14 & 1.00 & 5.00 \\
\hline & Wilcoxon two-samp & t-test, & $=-1.10$ & $; \mathrm{P}(\mathrm{Z}<-1$ & $10)=0.13$ & \\
\hline & Foundation phase & 24 & 3.59 & 0.87 & 2.00 & 5.00 \\
\hline Language & Intermediate phase & 12 & 4.00 & 1.13 & 1.00 & 5.00 \\
\hline & Wilcoxon two-samp & t-test, & $=1.52$ & $\mathrm{P}(\mathrm{Z}<1.5$ & 2) $=0.064^{\#}$ & \\
\hline & Foundation phase & 24 & 3.11 & 0.99 & 1.00 & 5.00 \\
\hline Bilingual & Intermediate phase & 12 & 3.33 & 1.44 & 1.00 & 5.00 \\
\hline & Wilcoxon two-samp & t-test, & $=0.68$ & $\mathrm{P}(\mathrm{Z}<0$. & $58)=0.25$ & \\
\hline & Foundation phase & 24 & 3.18 & 0.98 & 1.00 & 5.00 \\
\hline THRASS & Intermediate phase & 12 & 2.22 & 1.20 & 1.00 & 4.00 \\
\hline & Wilcoxon two-samp & t-test, & $z=-1.68$ & ; $\mathrm{P}(\mathrm{Z}<-$ & $.68)=0.05$ & \\
\hline & Foundation phase & 24 & 2.50 & 1.19 & 1.00 & 5.00 \\
\hline Internet & Intermediate phase & 12 & 3.18 & 1.54 & 1.00 & 5.00 \\
\hline & Wilcoxon two-samp & t-test. & $z=1.23$ & $\mathrm{P}(\mathrm{Z}<1$. & $3)=0.10^{\#}$ & \\
\hline $\begin{array}{l}\text { Significance } 1 \\
* * * \text { : statistica } \\
* * \quad: \text { statistica } \\
* \quad: \text { statistica } \\
\# \quad: \text { statistica }\end{array}$ & $\begin{array}{l}\text { legend: } \\
\text { l significance indica } \\
\text { l significance indica } \\
\text { l significance indica } \\
\text { l significance at the }\end{array}$ & at th & $\begin{array}{l}0.1 \% \text { le } \\
1 \% \text { lev } \\
5 \% \text { lev }\end{array}$ & of signi & ance & \\
\hline
\end{tabular}

The Wilcoxon test results in Table 1 indicate that for the phonic and THRASS methods there is a statistically significant difference (respectively at the $1 \%$ and $5 \%$ levels of significance) in the distribution of frequency-of-use levels of the Foundation phase teachers compared to the Intermediate phase teacher respondents. According to table 1, Foundation phase teachers use the phonic method always (mean rating of 4.76 which rounds to a frequency-of-use level 5) compared to the Intermediate phase teachers' average rating of often (mean rating of 4.08, rounds to 4). Similarly, it can be deduced that although the Foundation phase teachers use the THRASS programme less often or, as indicated, sometimes (mean $=3.18$, rounds 3 ); they use it statistically more than their Intermediate phase colleagues who use it very infrequently (mean $=2.22$ rounds to 2 ).

Regarding the interpretation of significance levels, the commonly accepted levels of significance are $0.1 \%, 1 \%$ and $5 \%$. For example, significance at the $5 \%$ level of significance which is most commonly used would mean that a specific finding has a $95 \%$ ( 1 - alpha) chance of being true. A significance level of $10 \%$ - a $90 \%$ chance, would therefore be riskier 
and would be regarded as 'suggesting' differences, not verifying differences (Creative Research Systems 2016).

Table 1 indicates that for the language experience method and internet-use aspects, statistical significance was only indicated at a $10 \%$ level of significance. Therefore, deductions regarding these two response datasets should only be regarded as suggestions of Foundation and Intermediate phase distribution differences over frequency-of-use rating levels. For the language experience method, the difference suggestion is subtle with a mean frequency-ofuse for the Intermediate phase teachers indicated as frequently (mean rating of 4.00) compared to the Foundation phase teachers who also indicated frequently but markedly less frequent than the Intermediate phase group (with a mean $=3.59$ rounds to 4 ). Similarly, for the use of the internet aspect, the difference-suggestion is subtle with mean frequency-of-use for the Intermediate phase teachers indicated as sometimes (mean rating of 3.18, which rounds to 3.0) compared to Foundation phase teachers also indicated as sometimes, but markedly less frequent than the Intermediate phase group (with a mean $=2.50$ rounds to 3 ). The use of the internet for stories to read doesn't seem to be popular among any participants.

\section{DISCUSSION}

From the data, it is clear that the Foundation phase teachers who were respondents in this study made good use of the phonic method to teach reading. This finding verifies that it is a general method often used in Foundation phase classrooms. All the respondents from the foundation phase indicated that they used the phonic method often or always. The look-andsay method was also used well in the Foundation phase compared to the comparison group of Intermediate phase teachers.

When learners move to the Intermediate phase, the teaching of the ability to read is not the main concern - as set out in the CAPS document for Grades 4 to 6. Grade 4 hails more formal education for learners as they are introduced to new and more subjects and they are expected to be able to read in order to learn. In the Intermediate phase, there is also an important shift in the reading process as learners no longer have to learn to read and instead have to read to learn.

The teachers in the Intermediate phase who were respondents in this study indicated that a group of them did use the phonic method and the look-and-say method sometimes (respectively $33.33 \%$ and $25.0 \%$ ), often (respectively $25.0 \%$ and $41.67 \%$ ) or always $(41.67 \%$ and $25.00 \%$ ). Knowledge of and using the two methods could be important to support Grade 4-6 learners whose reading abilities are below standard.

Research shows that there is no single reading method that can be considered the best to use but that a balanced approach that incorporates the various reading methods is advised (Adoniou 2017, Riddle, S 2015, Pressley \& Allington 2014, Pressley, Roehrig, Bogner, Raphael \& Dolezal 2002). The results of this study support this view. A combination of the phonic method and the look-and-say method may be the best to use because it incorporates learners' visual as well as their auditory learning abilities.

The combined or eclectic reading method necessitates the use of learners' auditory as well as visual skills. Syofyan and Siwi (2018:642) refer to the use of visual, auditory and kinaesthetic learning styles, which are the main learning styles used by learners. Learners use all their senses to absorb information but each learner has a preference as to how they learn best. 
Teachers should therefore try to incorporate the use of all learning styles into their teaching and also in the teaching of reading.

The eclectic method is very regularly (often and always) used by $13(59 \%)$ of the Foundation phase participants and sometimes by five $(22.72 \%)$ of these participants. An additional two responses $(9.1 \%)$ indicated a never rating. This reflects a somewhat higher use by Foundation phase teachers compared to half $(50.0 \%)$ of the respondents teaching in the Intermediate phase and in Grade 7 who indicated that they used the eclectic method very regularly (often and always). The ideal would be for all, or the majority of the participants in this study and also all primary school teachers, to use the eclectic method when necessary in their classrooms. This could help to support the many learners in the Intermediate phase who have reading problems as set out in the PIRLS report of 2016 and other reports on learners' reading abilities.

The participants in this study who taught Grade 1 to 3 learners indicated that some of them (63.64\%) did use the THRASS programme albeit only sometimes compared to the Grade 4 to 6 teachers who indicated that they use THRASS very infrequently rather than never $(51.52 \%)$. This raises the question of whether they know and use it at all. That would be unfortunate because the majority of South African learners use English as their second language of learning and teaching from Grade 4 onwards. If Intermediate phase teachers were familiar with the use of THRASS, it could be helpful to support English second language speaking learners when they encounter problems with pronunciation and spelling.

Regarding the language experience method, suggestions are (10\% level of significance) that the Intermediate phase and Grade 7 teachers incorporate this method on average, frequently (mean $=4.00)$ and the Foundation phase teachers on average, sometimes to frequently (mean $=3.59$ rounds to 4 ). The method was thus used to a somewhat lesser degree by respondents teaching in the Foundation phase and to a greater degree for learners in the Intermediate phase.

All the teachers indicated that they use the bilingual method, on average, sometimes. This finding should be considered against the background of learners' home language situation: In this research project, there were only two classes in the Foundation phase, both were Grade 1 classes and all the learners spoke one home language. In most other classes, two to three home languages were spoken in the classroom. Two classes reported four home languages and a further two classes recorded five spoken home languages. The situation with various spoken home languages in a single classroom was even worse when Intermediate phase classes were singled out: one class reported seven spoken home languages and another eight. One class had a learner whose home language was Portuguese.

The reading skills of learners whose home language was not the LoLT used in the class could be at risk. In South Africa with its 11 official home languages, the LoLT in the classroom is often a problem, especially from Grade 4 onwards when English as the LoLT is a second language for the majority of learners. Regarding reading in South African schools, Zimmerman and Smit (2014:2) emphasise how important it is to develop reading skills in the home language in the Foundation phase for those learners whose LoLT becomes English as their second language in Grade 4.

It is widely accepted that reading skills in a home language are transferred to a second language. According to Montes, Botero and Pechthalt (2009:68), it is especially reading 
comprehension that is transferred well from a learner's home language to a second language. If a learner experiences a reading problem, he or she could be supported by using the bilingual reading method.

Information about the participating teachers' use of the internet for teaching was obtained although it was not the main purpose of this discussion. Using the internet for stories to read was not popular among the participants as the Foundation phase teachers used it, on average, very infrequently (mean $=2.50$ rounds to 2 ) and their colleagues in the Intermediate phase used it sometimes $($ mean $=3.18$ round to 3 ).

\section{CONCLUSION}

The results from the analysis show that all the teachers made good use of the phonic method and the look-and-say methods to teach reading. The eclectic method was used to a lesser degree and participants indicated that they were not really acquainted with the THRASS method. It is a pity that the bilingual method and the language experience reading methods are not used by the teachers. These methods could be effective as scaffolding tools for additional or remedial reading in an attempt to meet the specific reading needs of learners, even if the learners are in Grades 4 to 6.

The data obtained from primary school teachers in three provinces verify that most of the respondents know and use some of the mentioned six reading methods. However, the research did not reveal how effective the primary school teachers use their knowledge of the various reading methods and how versatile they are in using reading methods according to the reading needs and learning styles of diverse learners. The belief that one method fits all certainly does not apply when it comes to the teaching of reading in primary school. With reference to the methods that teachers should use to teach reading, it is clear that teachers should be more versatile when selecting and using reading methods so that the diverse reading needs of their learners can be addressed.

\section{REFERENCES}

ADONIOU, M. 2017. How do we learn to read? The Conversation. 18 April 2017. Available from: https://theconversation.com>how... [Accessed: 1 February 2021].

ARIANDIKA, AG \& D KARTIKAWATI. 2018. Effective method of teaching reading (a case study). Journal Bahasa Lingua Scientia 10(2):275-286.

AUSTRALIAN DEPARTMENT OF EDUCATION. 2019. Literacy teaching toolkit. The language experience approach. Available at: www.education.vic.gov.au [Accessed: 20 April 2020].

BRYSKI, C. 2009. Increasing the Social Studies Reading Comprehension of Middle School Students with Learning Disabilities. Research project. Salt Lake City: Western Governors University. Available at: www.files.eric.gov [Accessed: 1 April 2021].

ENGEL, RJ \& RK SCHUTT. 2014. Fundamentals of social work research. $2^{\text {nd }}$ Edition. Sage Publications. Available: https://www.sagepub.com/sites/default/files/upmbinaries/61667_Chapter_6.pdf [Accessed 1 March 2021].

CREATIVE RESEARCH SYSTEMS. 2016. Creative Research Systems. 2016. Significancein statistics and surveys. What is statistical significance? Available from: https://www.surveysystem.com/signif.htm [Accessed 28 April 2020].

GARCÍA-MADRUGA, JA, ELOSUA, L, GIL, I, GóMEZ-VEIGA, JO, VILA, I, ORJALES, A, CONTRERAS, A, RODRIGUEZ, MA MELERO \& G DUQUE. 2013. Reading 
comprehension and working memory's executive processes: An intervention study in primary school students. Reading Research Quarterly, 48(2):155 - 174.

GENESSE, F. 2019. The home language: an English language learner's most valuable resource. Colorín Colorado a bilingual site for educators and families of English llanguage learners. Available from: https://www.colorincolorado.org/article/homelanguage-english-language-learners-most-valuable-resource?utm\%20content $=$ \&utm\%20medium=email\&utm\%20name $=\% 20$ source $=$ govdelivery\&utm $\% 20$ term [Accessed: 21 January 2019].

GREENBERG, B. 2009. Intro to the practice of Statistics. $6^{\text {th }}$ Edition. (EXCEL manual for Moore, McCabe and Craigh). WH Freeman Publishers: New York. Available at: http://bcs.whfreeman.com/webpub/statistics/ips6e/manuals/student_excel_manual/ips6e .ex.st.pdf [Accessed 2 March 2021].

JOUBERT, I. 2013. Literacy in the foundation phase. Van Schaik: Pretoria.

LAMARCA, N. 2011. The Likert scale: advantages and disadvantages. Field research in organizational psychology. Available from: https://psyc450.wordpress.com [Accessed: 5 December 2011].

LE CORDEUR, M. 2010. From 0 to $100 \%$ - How Raithby Primary turned their literacy performance around. Journal of Education, 49:35-62.

MCBRIDE, SL. 2019. Why are South African children struggling to read properly? Available from: https://africasacountry.com/2019/04/why-are-south-african-children-strugglingto-read-properly [Accessed on 20 August 2021].

MONTES, F, MP BOTERO \& T PECHTHALT. 2009. Reading Comprehension from a First a Second Language. GIST - Education and Learning Research Journal 3:53-73.

MULLIS, IVS, MO MARTIN, P FOY \& M HOOPER. 2017, PIRLS 2016 international results in reading, TIMSS and PIRLS International Study Center, Lynch School of Education, Boston College and International Association for the Evaluation of Educational Achievement.

NATIONAL DEPARTMENT OF BASIC EDUCATION 2011(a). Curriculum and Assessment Policy Statement. Home language Grades R - 3. Pretoria: Government Printing Works.

NATIONAL DEPARTMENT OF BASIC EDUCATION (2011(b). Curriculum and Assessment Policy Statement. Grades $4-6$. English home language. Pretoria: Government Printing Works.

NATIONAL RESEARCH COUNCIL. 2010. Preparing teachers: building evidence for sound policy. 5 Preparing reading teachers. National Academies Press. Available from: https://www.nap.edu/catalog/12882/preparing-teachers-building-evidence-forsound-policy [Accessed: 31 March 2020].

OFUANI, FN \& UB GBENEDIO. 2016. The Effectiveness of Three Methods of Teaching Reading on Students' Achievement in Comprehension. Journal of Educational and Social Research. 6(1):17-21.

OLLIS, I. 2017. 78\% Grade 4 illiteracy rate must be probed. Available from: www.politicsweb.co.za/documents/78-illiteracy-rates-must-be-probed-ian-ollis [Accessed: 7 February 2020].

OXLEY, S. 2014. Phonics tests and literacy: reading is more than just 'barking at print'. The Guardian 29 September 2014. Available from: www.theguardian.com>sep [Accessed on 1 February 2021].

PICTON, I. 2019. Teachers' use of technology to support literacy in 2018. National Literacy Trust. 
https://cdn.literacytrust.org.uk/media/documents/Teachers_Use_of_Technology_report. pdf [Accessed: 2 March 2021].

PRESSLEY, M \& R ALLINGTON. 2014. Reading instruction that works: a case for balanced teaching. New York: Guilford Press.

PRESSLEY, M, ROEHRIG, A, BOGNER, K, RAPHAEL, LM \& S DOLEZAL. 2002. Balanced literacy instruction. Focus on exceptional children. 34(5): 2-15.

RIDDLE, S. 2015. A balanced approach is best for teaching kids to read. The Conversation. Available from: https://the conversation.com>a ba...Accessed: 10 January 2020].

ROIG-VILA, R \& S MENGUAL-ANDRéS. 2014. New literacy for reading using ICT. ECPS Journal 10:431-441.

RULE, P \& S LAND. 2017. Finding the plot in the South African reading education. Reading \& Writing - Journal of the Reading Association of South Africa. 8(1): 2308-1422.

STRAUSS, V. 2019. A case for why both sides in the 'reading wars' are wrong. The Washington Post. 27 March 2019.

SYOFYAN, R \& MK SIWI. 2018. The impact of visual, auditory and kinaesthetic learning styles in economics education teaching. Advances in Economics, Business and Management Research 57:642-649.

TESSA Methods for teaching reading. Method 2 Look-and-say. Available from: https://www.open.edu> oucontent [Accessed: 17 February 2020].

TSHUMA, L \& M LE CORDEUR. 2017. Taal as hulpbron in Intermediêre Fase wiskundeonderrig in die Oos-Kaap: Op soek na 'n effektiewe pedagogiek vir wiskundeonderrig. Tydskrif vir Geesteswetenskappe 57(3):707-723.

UNESCO 2004. Teaching reading in primary schools - UNESCO digital library. Available from: https://pdf4pro.com<amp<view. [Accessed: 2 February 2020].

WHAT IS THRASS? - Thrass. Available from: www.thrassafrica.co.za [Accessed: 13 March 2020].

ZIMMERMAN, L \& B Smit. 2014. Profiling classroom reading comprehension development practices from the PIRLS 2006 in South Africa. South African Journal of Education 34:3:109. Available from: http://www.sajournalofeducation.co.za [Accessed: 10 February 2020].

\section{BIOGRAPHICAL NOTE}

Anna Hugo is a research associate and emeritus professor in the Department of Language Education, Arts and Culture in the College of Education at the University of South Africa. Her research foci include reading in the Foundation phase and the teaching of a second language in the Foundation phase. Her fields of interest are the teaching of a language and inclusive education. Email address: annajohugo@gmail.com 